\title{
PENGGUNAAN TEPUNG LIMBAH PENGALENGAN IKAN DALAM RANSUM TERHADAP KUALITAS KARKAS BROILER
}

\author{
Etias Gombo*, M. Najoan $^{* *}$, F. R.Wolayan ${ }^{* *}$ M. R. Imbar ${ }^{* * *}$ \\ Fakultas Peternakan Universitas Sam Ratulangi Manado, 95115
}

\begin{abstract}
ABSTRAK
Penelitian tentang penggunaan tepung ikan berbasis limbah hasil pengolahan pengalengan ikan telah dilaksanakan untuk mengetahui pengaruhnya terhadap kualitas karkas.Tepung limbah pengalengan ikan yang digunakan diperoleh dari pabrik pengolahan ikan kaleng di Kota Bitung Sulawesi Utara.Penelitian ini menggunakan 60 ekor broiler, dipelihara sejak umur 1 sampai 42 hari.Rancangan yang digunakan adalah Rancangan Acak Lengkap (RAL) dengan 4 perlakuan dan 5 ulangan. Perlakuan tersebut adalah beberapa tingkat pemberian tepung limbah pengalengan ikan yaitu $\mathrm{R}_{1}=8 \%, \mathrm{R}_{2}=$ $10 \%, \mathrm{R}_{3}=12 \%, \mathrm{R}_{4}=14 \%$. Peubah yang diukur guna melihat pengaruh penggunaan tepung limbah pengalengan ikan terhadap kualitas karkas yaitu persentase karkas, persentase lemak abdomen dan persentase hati.

Hasil analisis keragaman menunjukkan perlakuan memberikan pengaruh berbeda tidak nyata $(\mathrm{P}>0,05)$ terhadap persentase karkas (71,13-72,90\%) dan persentase hati $(1,82-2,22 \%$, namun memberikan pengaruh berbeda nyata terhadap persentase lemak abdomen. Hasil uji lanjut BNJ menunjukkan persentase lemak abdomen broiler diberi ransum $8 \%$ tepung limbah pengalengan ikan $(3,27 \%)$ nyata lebih tinggi dari $10 \%$ tepung limbah pengalengan ikan $(2,76 \%)$ dan $12 \%$ tepung limbah pengalengan ikan $(2,75 \%)$, sedangkan antara $R_{2}$ dan $R_{3}$ berbeda tidak nyata atau sama, tetapi nyata lebih tinggi dibanding dengan yang mendapatkan $14 \%$ tepung limbah pengalengan ikan $(1,84 \%)$.Berdasarkan penelitian ini dapat ditarik kesimpulan bahwa penggunaan tepung limbah pengalengan ikan sampai $14 \%$ dalam ransum broiler, menghasilkan kualitas karkas yang baik.
\end{abstract}

\footnotetext{
*Alumni

** Jurusan Nutrisi dan Makanan Ternak
}

Kata Kunci: Limbah pengalengan ikan, kualitas karkas broiler.

\begin{abstract}
USE OF WASTE CANNING MEAL IN THE QUALITY OF CARCASS BROILER RATION. A research evaluating the effects of the utilization of fish meal based on canned fish waste product of fish processing plant in Bitung, Nort Sulawesi. This research used 60 broiler day old chick. The research had been conducted for 42 days. Completely Randomized Design (CRD) will 4 treatments and 5 replications was used the treatments were sereal level of canned fish waste product $: \mathrm{R}_{1}=8 \%, \mathrm{R}_{2}=10 \%, \mathrm{R}_{3}=12 \%$, $\mathrm{R}_{4}=14 \%$. Variables measured was carcass quality crusisting of carcass percentage, abdominal fat percentage, and liver percentage.

The results showed that there were no significant differences $(\mathrm{P}>0.05)$ on carcass percentage $(71,13-72,90 \%)$ and liver percentage $(1,82-2,22 \%)$; Howerer there was significant differences $(\mathrm{P}<0.05)$ on abdominal fat. Honestly significant difference (HSD) test thormed that abdominal fat percentage of broiler fed $8 \%$ fish canned fish by product $(3,27 \%)$ was significanly $(\mathrm{P}<0.05)$ higher than broiler fed $10 \%(2,76 \%)$ and $12 \%(2,75 \%)$, there was no significant difference between $\mathrm{R}_{2}$ and $\mathrm{R}_{3}$, However significantly higher than broiler fed $14 \%$ canned fish by product $(1,84 \%)$. It can be concluded that the utilization of canned fish meal by product up to $14 \%$ in the ration can produce a good quality carcass.
\end{abstract}

Key words: Fish meal, canned fish by product, carcass quality 


\section{PENDAHULUAN}

Broiler merupakan salah satu ternak unggulan yang dibudidayakan sebagai penghasil daging, sebab daging ayam dapat memenuhi kebutuhan protein hewani masyarakat. Selain itu harganya relatif murah dan dapat dijangkau oleh semua kalangan masyarakat. Broiler membutuhkan zat-zat makanan untuk hidup pokok, pertumbuhan, dan produksi.Secara garis besar zat-zat makanan yang dibutuhkan broiler yaitu protein, karbohidrat, lemak, vitamin, mineral, dan air. Protein merupakan salah satu unsur gizi yang sangat penting bagi kehidupan ternak khususnya untuk pertumbuhan.

Bahan pakan yang digunakan dapat menentukan kualitas sehingga dalam penyusunan ransum perlu diperhatikan terutama bahan pakan sumber protein, sebab protein merupakan salah satu komponen gizi yang sangat esensial bagi kehidupan ternak karena dibutuhkan untuk pertumbuhan jaringan dan menggantikan sel-sel tubuh yang rusak. Apabila terjadi defisiensi protein atau defisiensi salah satu asam amino tunggal akan menyebabkan kehilangan pertumbuhan rata-rata sebesar 6-7\% dari bobot badan perhari, sebaliknya apabila kelebihan protein, meskipun semua asam amino esensial seimbang akan mengakibatkan terjadi penimbunan lemak tubuh.

Limbah yang dihasilkan dari kegiatan perikanan masih cukup tinggi, yaitu sekitar 20-30\%. Produksi ikan mencapai 6,5 juta ton pertahun di Indonesia (FAO, Rome, 1997). Hal ini berarti sekitar 2 juta ton terbuang sebagai limbah. Limbah yang dihasilkan dari kegiatan perikanan adalah limbah berbentuk padat berupa potongan daging ikan, sisik, dan insang. Limbah ikan yang berbentuk cair antara lain darah, lendir dan air cucian. Sedangkan limbah ikan yang berbentuk gas adalah bau yang ditimbulkan karena adanya senyawa amonia, hidrogen sulfida atau keton.(Anonymous, 2010).

Perairan Sulawesi utara terkenal dengan produksi ikan cakalang (Katsuwonus pelamis L), Data dari Dinas Perikanan Provinsi Sulawesi Utara produksi ikan cakalang tahun 2009 sebesar 60.8903 ton, tahun 2010 sebesar 60.1681 ton, maka produksi limbah ikan $(30 \% \mathrm{x}$ 60168 /tahun: 18.000 ton /tahun), dapat dimanfaatkan untuk pakan ternak. Daerah Sulawesi Utara khususnya Kota Bitung cukup terkenal sebagai daerah yang memiliki industri pengolahan hasil perikanan berskala ekspor seperti industri ikan kaleng, ikan kayu, dan ikan asap. Ikan yang digunakan umumnya adalah 
jenis ikan pelangis besar maupun kecil seperti tuna, cakalang dan deho. Berkembangnya industri pengolahan ikan ini mengakibatkan melimpahnya produk ikutan, yaitu limbah ikan yang sesungguhnya dapat dimanfaatkan sebagai bahan baku tepung ikan. Selain itudi kota Bitung terdapat juga industri pengalengan ikan yang telah mengolah limbah menjadi tepung ikan (Fish meal). Tepung ikan yang dihasilkan oleh industri tersebut, sudah diolah secara komersial bahkan telah menjadi produk yang diekspor.

Salah satu sumber protein dalam penyusun ransum broiler yaitu tepung ikan, umumnya berasal dari ikan-ikan yang tidak dimanfaatkan untuk manusia atau sisa pengalengan. Limbah ikan terdiri dari kepala, isi perut, tulang, dan insang. Sumber protein penyusun ransum broiler yaitu tepung ikan teri yang masih bersaing dengan manusia sehingga harganya mahal, oleh karena itu perlu dicari pakan alternatif lain, mudah didapat dan harganya murah. Pemanfaatan limbah pengalengan ikan merupakan salah satu sumber protein dalam menyusunan ransum, sebab kandungan protein limbah pengalengan ikan yaitu 58,52\% (Sucofindo, 2013). Secara umum produksi limbah ikan cakalang tergantung pada proses pengolahan industri dan bagian yang berupa by product atau limbah adalah bagian jeroan, insang, daging coklat, kepala, tulang, dan kulit. Perbandingan bagian tubuh tersebut terdiri dari kepala $11-26 \%$, tulang dan sirip 8,2\%, insang $3,3 \%$, isi perut $6,6 \%$, daging dan kulit $60,8-66,0 \%$.

Sulawesi Utara sebagai penghasil ikan dan tersedianya bahan baku tepung ikan berbasis limbah pengolahan ikan merupakan potensi untuk dikembangkan, diantaranya dengan memanfaatkan produk tersebut sebagai sumber protein hewani dalam ransum broiler. Penelitian ini bertujuan untuk mengetahui pengaruh penggunaan tepung ikan berbasis limbah pengalengan ikan terhadap kualitas karkas broiler. Selain itu hasil penelitian ini diharapkan menjadi acuan informasi ilmiah khususnya tentang sumber lain protein hewani, yaitu tepung limbah pengalengan ikan.

\section{MATERI DAN METODE PENELITIAN}

Penelitian ini dilaksanakan dikandang unggas Jurusan Nutrisi dan Makanan Ternak Fakultas Peternakan Universitas Sam Ratulangi Manado selama 4 minggu, sejak tanggal 25 Agustus sampai 22 September 2014. Ternak yang digunakan dalam penelitian ini, yaitu broiler berumur 14 hari yang dipelihara 
sejak umur 1 hari, strain CP 707 sebanyak 60 ekor.

Broiler ditempatkan dalam kandang sistem battery terbuat dari kawat,setelah broiler berumur 14 hari. Ukuran masing-masing unit kandang adalah $60 \times 45 \times 45 \mathrm{~cm}$. Penelitian ini menggunakan 20 unit kandang dan setiap kandang ditempati 3 ekor broiler. Didalam setiap unit kandang dilengkapi dengan tempat makan dan minum.

Tabel 1. Kandungan Zat Makanan dan Energi Metabolis dari Bahan Pakan Penyusun Ransum

\begin{tabular}{lrrrrrrr}
\hline Bahan Pakan (\%) & Protein & Lemak & SK & Abu & Ca & P & ME \\
\hline Jagung* & 9,42 & 5,17 & 2,15 & 15,13 & 0,22 & 0,60 & $2,983,50$ \\
Dedak* & 13,44 & 6,07 & 6,35 & 10,33 & 0,19 & 0,73 & $2,695,50$ \\
Bungkil Kelapa* & 24,74 & 9,36 & 15,02 & 6,95 & 0,11 & 0,47 & $3,279,75$ \\
Tepung Kedele*** & 40,38 & 9,91 & 6,56 & - & 0,24 & 0,58 & $2,540,00$ \\
T.Limbah Pengalengan Ikan** & 58,52 & 13,90 & 2,95 & 25,11 & 7,04 & 3,67 & $3,851,80$ \\
Minyak* & - & 100,00 & - & - & - & - & $8,812,00$ \\
Top Mix* & - & - & - & - & 5,38 & 1,44 & - \\
\hline Ket: & - & & & & & &
\end{tabular}

Ket: ***Hasil analisis Kowel, 2007

**Hasil Analisis Sucofindo, 2013

*Hasil Analisis Laboratorium Ternak Ruminansia dan Kimia Makanan Fakultas Peternakan Unpad, 2013

Tabel 2. Komposisi Zat-zat Makanan dan Energi Ransum Penelitian

\begin{tabular}{lrrrr}
\hline Bahan Pakan (\%) & $\mathrm{R} 1$ & $\mathrm{R} 2$ & $\mathrm{R} 3$ & $\mathrm{R} 4$ \\
\hline Jagung & 50,50 & 50,50 & 50,50 & 50,50 \\
Dedak & 10,00 & 10,00 & 10,00 & 10,00 \\
Bungkil Kelapa & 12,00 & 12,00 & 12,00 & 12,00 \\
Tepung Kedele & 17,50 & 15,50 & 13,50 & 11,50 \\
T. Limbah Pengalengan Ikan & 8 & 10 & 12 & 14 \\
Minyak & 1,00 & 1,00 & 1,00 & 1,00 \\
Top Mix & 1,00 & 1,00 & 1,00 & 1,00 \\
\hline Total & 100,00 & 100,00 & 100,00 & 100,00 \\
\hline Protein (\%) & 20,82 & 21,18 & 21,54 & 21,91 \\
Lemak (\%) & 8,19 & 8,27 & 8,35 & 8,69 \\
Serat Kasar (\%) & 4,91 & 4,83 & 4,76 & 4,65 \\
Ca (\%) & 0,80 & 0,94 & 1,07 & 1,21 \\
P $(\%)$ & 0,84 & 0,90 & 0,97 & 1,03 \\
Abu (\%) & 11,52 & 12,02 & 12,52 & 13,02 \\
ME (kkal/kg) & 3010,55 & 3036,79 & 3063,02 & 3089,26 \\
\hline
\end{tabular}

Ket: Dihitung berdasarkan komposisi zat-zat makanan pada Tabel 1. 
Kandang-kandang tersebut ditempatkan dalam ruangan dengan ventilasi dan cahaya yang cukup. Peralatan yang digunakan adalah timbangan (analog dan digital), beberapa ukuran kantong plastik, dan wadah untuk menyusun ransum.

Ransum yang digunakan dalam penelitian ini disusun dari beberapa bahan pakan, yaitu jagung kuning, dedak halus, bungkil kelapa, tepung kelede, dan topmix. Selain itu menggunakan minyak kelapa untuk mencukupkan kebutuhan energi ransum. Komposisi zat makanan dan energi metabolis dari bahan pakan penyusun ransum dan komposisi ransum penelitian dapat dilihat pada Tabel 1 .

Formula ransum perlakuan terdiri dari :

R1 = Limbah pengalengan ikan $8 \%$

R2 = Limbah pengalengan ikan $10 \%$

R3 = Limbah pengalengan ikan $12 \%$

R4 = Limbah pengalengan ikan 14\%

Penelitian ini menggunakan Rancangan Acak Lengkap (RAL) menurut petunjuk Steel dan Torrie, (1993) yang terdiri dari 4 perlakuan dan 5 ulangan. Respon broiler terhadap penggunaan tepung limbah pengalengan ikan dalam ransum diukur melalui:

1. Persentase karkas (diperoleh dari perbandingan antara bobot karkas (gram) dengan bobot hidup (gram) dikalikan 100\%).
Persentase karkas
$=\frac{\text { Bobot Karkas }(\mathrm{gram})}{\text { Bobot Hidup }(\mathrm{gram})} \times 100 \%$

2. Persentase lemak abdomen (diperoleh dari perbandingan antara bobot lemak abdomen (gram) dengan bobot hidup (gram) dikalikan 100\%).

Persentase Lemak Abdomen

$=\frac{\text { Bobot Lemak Abdomen }(\text { gram })}{\text { Bobot Hidup }(\text { gram })} \times 100 \%$

3. Persentase hati (diperoleh dari perbandingan antara bobot hati (gram) dengan bobot hidup (gram) dikalikan $100 \%$ ).

Persentase Hati

$=\frac{\text { Bobot Hati }(\mathrm{gram})}{\text { Bobot Hidup }(\mathrm{gram})} \times 100 \%$

\section{HASIL DAN PEMBAHASAN}

Data hasil penelitian pengaruh perlakuan terhadap kualitas karkas yang terdiri atas persentase karkas, persentase lemak abdomen, dan persentase hati dapat dilihat pada Tabel 3 .

\section{Pengaruh Perlakuan Terhadap}

\section{Persentase Karkas}

Hasil pengamatan nilai rata-rata persentase karkas broiler selama penelitian berkisar antara 71,13-72,90\%.Analisis ragam digunakan untuk melihat pengaruh perlakuan terhadap nilai persentase karkas.

Hasil analisis sidik ragam menunjukkan bahwa perlakuan ransum yang mengandung tepung limbah pengalengan ikan berbeda tidak nyata $(\mathrm{P}>0,05)$ terhadap persentase karkas. 
Tabel 3. Rataan Persentase Karkas, Lemak Abdomen, dan Hati Selama Penelitian.

\begin{tabular}{lcccc}
\hline \multirow{2}{*}{ Kualitas Karkas } & \multicolumn{4}{c}{ Perlakuan } \\
\cline { 2 - 5 } & $\mathrm{R}_{1}$ & $\mathrm{R}_{2}$ & $\mathrm{R}_{3}$ & $\mathrm{R}_{4}$ \\
\hline Persentase Karkas & 71,13 & 71,62 & 71,98 & 72,90 \\
Persentase Lemak Abdomen & $3,27^{\mathrm{a}}$ & $2,76^{\mathrm{b}}$ & $2,75^{\mathrm{b}}$ & $1,84^{\mathrm{c}}$ \\
Persentase Hati & 2,22 & 2,10 & 2,20 & 1,84 \\
\hline Ket $: \quad$ Nilai dengan superskrip yang berbeda menunjukkan perbedaan yang nyata (P<0,05)
\end{tabular}

Ket : Nilai dengan superskrip yang berbeda menunjukkan perbedaan yang nyata $(\mathrm{P}<0,05)$

Artinya penggunaan tepung limbah pengalengan ikan sampai $14 \%$ dalam ransum, tidak berpengaruh terhadap persentase karkas ataubroiler merespon sama terhadap semua ransum perlakuan, sehingga tidak mempengaruhi persentase karkas. Persentase karkas hasil penelitian ini berkisar 71,13-72,90\%, hal ini masih sejalan dengan yang dilaporkan Aviagen (2006) rata-rata persentase karkas broiler berkisar antara $71-73 \%$ dari bobot badan. Demikian pula North dan Bell (1990) bahwa persentase karkas "Ready to Cook" adalah $70-77 \%$ dari bobot hidupnya. Selanjutnya Murtidjo (2003) menyatakan rataan bobot karkas broiler berkisar antara $65-75 \%$ dari berat hidup pada waktu siap dipotong.

Berbeda tidak nyata antara perlakuan disebabkan kandungan zat-zat makanan dari ransum khususnya protein yang berfungsi sebagai bahan pembentuk jaringan, dalam penelitian ini masih sesuai dengan standar kebutuhan yang direkomendasikan oleh Suprijatna dkk (2005) kebutuhan protein untuk broiler 20$23 \%$ /ekor/hari. Selanjutnya Scott dkk (1984) menyatakan bahwa pakan harus mengandung zat nutrisi dalam keadaan cukup dan seimbang sehingga dapat menunjang pertumbuhan maksimal dan menghasilkan bobot akhir yang tinggi. Menurut Indarto (2010), untuk mencapai pertumbuhan yang baik dalam produk broiler, ransum yang diberikan harus sempurna dan mencukupi dalam arti ransum yang diberikan mengandung semua zat-zat makanan yang diperlukan oleh tubuh dengan kualitas yang baik dalam jumlah yang sesuai dengan kebutuhan.

\section{Pengaruh Perlakuan Terhadap Persentase Lemak Abdomen}

Hasil pengamatan nilai rata-rata persentase karkas broiler selama penelitian berkisar antara 1,84-3,27\%. Analisis ragam digunakan untuk melihat pengaruh 
perlakuan terhadap nilai persentase lemak abdomen.

$\begin{array}{rrr}\text { Hasil analisis } & \text { keragaman } \\ \text { menunjukkan } & \text { bahwa } & \text { perlakuan }\end{array}$
memberikan pengaruh yang berbeda nyata $(\mathrm{P}<0,05) \quad$ terhadap penurunan persentaselemak abdomen broiler. Hasil uji lanjut BNJ menunjukkan bahwa persentase lemak abdomenbroiler yang diberi ransum $\mathrm{R}_{1}$ (8\% tepung limbah pengalengan ikan) nyata lebih tinggi dari $\mathrm{R}_{2} \quad(10 \%$ tepung limbah pengalengan ikan), $R_{3}$ (12\% tepung limbah pengalengan ikan) dan $\mathrm{R}_{4}$ (tepung limbah pengalengan ikan), sedangkan antara $\mathrm{R}_{2}$ dan $\mathrm{R}_{3}$ berbeda tidak nyata atau sama, namunnyata lebih tinggi dibanding dengan yang mendapatkan14\% tepung limbah pengalengan ikan. Keadaan ini membuktikan bahwa, semakin tinggi penggunaan tepung limbah pengalengan ikan dalam ransum makin rendah persentase lemak abdomennya. Ratio kalsium dan posfor juga hampir sama, pada semua ransum perlakuan tetapi ada kecenderungan meningkat secara kuantitas. Mengingat kalsium dan posfor tergolong mikro nutrien sehingga peningkatan kalsium dan posfor sedikit dapat mempegaruhi proses metabolisme dalam tubuh. Khususnya posfor, punya peranan yang sangat penting dalam proses metabolisme energi, karbohidrat, lemak dan asam-asam amino. (Wahyu, 2004, Scott dkk 1982). Posfor dibutuhkan hamper semua proses yang ada sangkut pautnyadengan energi dalam sel-sel hidup, sebagian besar proses metabolisme dalam tubuh selalu berhubungan dengan energi (Parakkasi, 1983).

Posfor juga merupakan bagian penting dari enzim, sebagai pengaktif enzim (kofaktor) dalam penyimpanan dan mengubah energi, dan yang tak kalah pentingnya posfor sebagai alat transportasi, asam-asam lemak dari lipida lainnya ke dalam aliran darah masuk ke cairan interseluler dan kedalam sel, sehingga semakin banyak posfor dalam ransum, akan semakin banyak lemak yang ditransport ke cairan interseluler dan kedalam selyang pada gilirannya semakin sedikit lemak tertimbun dalam lemak abdomen. Hal ini sejalan dengan hasil penelitian tentang pertambahan bobot badan broiler yang diberi $14 \%$ tepung limbah pengalengan ikan yang paling tinggi dibanding dengan perlakuan ransum yang mengandung $12 \%\left(\mathrm{R}_{3}\right), 10 \%\left(\mathrm{R}_{2}\right)$ dan $8 \%\left(\mathrm{R}_{1}\right)$.

\section{Pengaruh Perlakuan Terhadap}

\section{Persentase Hati}

Hasil pengamatan nilai rata-rata persentase karkas broiler selama penelitian berkisar antara 1,82-2,22\%. Analisis 
ragam digunakan untuk melihat pengaruh perlakuan terhadap nilai persentase hati.

$\begin{array}{rlr}\text { Hasil } & \text { analisis } & \text { keragaman } \\ \text { menunjukkan } & \text { pengaruh } & \text { perlakuan }\end{array}$
penggunaan tepung limbah pengalengan ikan berbeda tidak nyata $(\mathrm{P}>0,05)$ terhadap rataan persentase hati. Rataan persentase hati pada penelitian ini berkisar antara, $1,82-2,22 \%$, sejalan dengan yang dilaporkan oleh Carwell dkk (1980), bahwa persentase hati untuk broiler umur 6 minggu berkisar antara 1,73-2,3\% dari bobot hidup.

Tidak berbedapersentase hati pada penelitian ini disebabkan oleh fungsi fisiologis hati merespon sama terhadap semua perlakuan yang diberikan. Adapun fungsi hati adalah merupakan pusat metabolisme zat-zat makanan seperti protein, karbohidrat dan lemak, pengemulsi lemak, menyimpan energi siap pakai (glikogen) serta menguraikan hasil sisa protein menjadi asam urat dikeluarkan melalui ginjal (Blakely and Bade 1991). Pada saat kekurangan energi, maka glikogen yang tersimpan dalam hati dirubah menjadi glukosa, sebaliknya jika tubuh kelebihan energi maka akan dirubah menjadi glikogen hati, jadi semua zat-zat makanan dari keempat perlakuan ransum masih berada pada batas toleransi hati untuk menjalankan fungsinya sehingga tidak berdampak pada peningkatan persentase hati atau penurunan persentase hati (hypertrophy atau nekrosis).

\section{KESIMPULAN}

Berdasarkan hasil penelitian ini, dapat ditarik kesimpulan bahwa penggunaan tepung limbah pengalengan ikan sampai $14 \%$ dalam ransum broiler, menghasilkan kualitas karkas yang baik.

\section{DAFTAR PUSTAKA}

Aviagen. Arbor Acres Plus(Efficient Meat Production Plus Excellent Breeder

Performance).Http://Www.Aviage n.Com//Ayam/\%20/Broiler//Files/ Brosur.Ficient// Meat//Production_/Plus/Excellent // Breeder// Performance_// Html”. 24 RdJuli 2006

Annonymous ${ }^{\mathrm{a}}$, 2010.Penanganan Limbah Hasil Perikanan Secara Biologis. Http://

Eafrianto.Wordpress.Com/2009/1 2/10.

Blakely, J and D. H. Bade. 1991. Ilmu Peternakan. Diterjemahkan oleh Srigandono, Bambang. Universitas Gadjah Mada. Press Yogyakarta.

Carwll, S. W., D. R. Sloan and R. K. Hale. 1980. Yield And Composition Of Edible and Inedible By-Product Of Broiler Processed At 6,7 and 8 Week Of Age. 59:2244-2246 
Food and Agriculture Organization of the United Nations (FAO), The State of World Fisheriesand Aquaculture, 1996 (FAO, Rome, 1997),

Indarto, N. 2010. Sukses dan Untung Besar Beternak Ayam Broiler.Lumine Books.Yogyakarta.

Kowel, Y. H. S. 2007 Pengaruh Penggunaan Limbah Minyak Pengalengan Ikan dalam Ransum Terhadap Efisiensi Biologis dan Kualitas Karkas Broiler. Tesis. Universitas Sam Ratulangi. Program Pasca Sarjana.

Murtidjo B. A. 2003. Pedoman Beternak Ayam Broiler. Kanisius, Yogyakarta.

North, M.D, and D.D. Bell. 1992. Commercial Chicken Production Manual. $2^{\text {nd }}$ Edition. The Avi Publishing Co. Inc. Wesport, Conecticut.

Parakkasi, A. 1983. Ilmu Gizi dan Makanan Ternak Monogastrik. Angkasa Bandung
Scott, M.L ., Malden C. Neshiem, Robert J. Young. 1982. Nutrition of The Chicken. 3rd ed. M. L Scott and Assotition Ithace. New York.

Soeparno. 1994. Ilmu dan Teknologi Daging. Universitas Gadjah Mada.Press.Yogyakarta.

Sucofindo. 2013. Laporan Hasil Analisis LAB Tepung Ikan

Suprijatna, E., U. Atmomarsono dan R. Kartasudjana. 2005. Ilmu Dasar Ternak Unggas. Penebar Swadaya. Jakarta.

Steel, R. G. D., dan J. H. Torrie. 1993. Prinsip dan Prosedur Statistika. Edisi Kedua. Terjemahan: B. Sumantri.

Yamin, M. 2002. Pengaruh Tingkat Protein Pakan terhadap Konsumsi, Pertambahan BobotBadan dan IOFC Ayam Buras Umur 0-8 Minggu.

Wahyu. 2004. Ilmu Nutrisi Unggas. $5^{\text {rd }}$. Universitas Gadjah Mada Press. Yogyakarta. 